\title{
Cruel and usual punishment: solitary confinement in Canadian prisons
}

\author{
Diane Kelsall MD MEd
}

$\mathrm{O}$ $\mathrm{n}$ any given day, there are 850 offenders (about 5.6\% of the prison population) in solitary confinement in Canadian federal prisons. ${ }^{1}$ Some of these inmates have been isolated for more than four months. Many are young. Many have serious mental health problems. Is this acceptable practice or is this torture?

Solitary confinement, defined as physical isolation for 22 to 24 hours per day ${ }^{2}$ and termed "administrative segregation" in federal prisons, has substantial health effects. These effects may develop within a few days and increase the longer segregation lasts. Anxiety, depression and anger commonly occur. ${ }^{3}$ Isolated prisoners have difficulty separating reality from their own thoughts, which may lead to confused thought processes, perceptual distortions, paranoia and psychosis., ${ }^{3,4}$ In addition to the worsening of preexisting medical conditions, offenders may experience physical effects, such as lethargy, insomnia, palpitations and anorexia. ${ }^{3}$

Those in solitary confinement are at increased risk of selfharm and suicide. ${ }^{3,5}$ Over the past three years, nearly half of suicides (14/30) in federal prisons occurred in segregation cells; most of these inmates had known serious mental health conditions. ${ }^{6}$

The mental and physical health effects are thought to be a result of the profound lack of stimulation and social interaction that occurs in solitary confinement, combined with the lack of control over daily life inherent in incarceration. ${ }^{3}$ Under Canadian regulations, inmates may be segregated if the institutional head believes the inmate may be at risk of harming others, being harmed or interfering with a criminal investigation. ${ }^{7}$ Isolation can be voluntary, but most placements in federal prisons (83\%) are involuntary or are for disciplinary reasons. ${ }^{5}$

A growing body of literature shows that solitary confinement can change brain activity and result in symptomatology within seven days. ${ }^{3,4}$ The effects may resolve after the offender is reintegrated into the general prison population., ${ }^{3,4}$ Some effects may be long term or permanent in those who are isolated for lengthy periods, particularly if they are young or have preexisting mental health conditions. ${ }^{4,6}$ Long-term effects include impaired memory, confusion, depression, phobias and personality changes, which may affect the offender's ability to successfully reintegrate into society upon release. ${ }^{4}$

Because a fundamental purpose of incarceration is to "prepare offenders for their safe, gradual and structured release to the community," placing inmates in lengthy segregation that results in damage to their mental and physical health is counter to that goal. Yet the use of solitary confinement is becoming more common in federal prisons (an increase of $6.4 \%$ over the past five years), and stays can be long. Inmates placed in segregation are also those more likely to be at risk of associated health effects. ${ }^{1}$
In 2011/12, nearly $25 \%$ of the entire population in federal prisons spent some time in segregation. ${ }^{8}$ Violent offenders are the largest category of isolated prisoners, but younger offenders are nearly twice as likely to be segregated as the general prison population $(7.1 \%$ v. $3.7 \%) .{ }^{1}$ Offenders with concurrent substance abuse and mental health disorders are also more likely to be isolated. ${ }^{1,6}$ The average length of stay in isolation is 35 days for a man and 7 days for a woman; $16 \%$ of those segregated are there for more than 120 days. Those placed in solitary confinement are often sent there again. ${ }^{6}$

Although Aboriginal people comprise about $4 \%$ of Canada's population, they are overrepresented in prisons, accounting for $23 \%$ of the prison population. ${ }^{1}$ If incarcerated, nearly one-third spend some time in solitary confinement, for an average of five days longer than a non-Aboriginal offender. ${ }^{5}$

The Correctional Investigator, appointed as ombudsman for federal offenders, has repeatedly called for a prohibition on long-term segregation of seriously mentally ill, self-injurious or suicidal inmates. The United Nations Special Rapporteur of the Human Rights Council has said that any period of more than 15 consecutive days in solitary confinement constitutes a form of torture and that lengthier terms, isolation of juveniles and use of segregation for punishment should be prohibited. ${ }^{4}$ Even shorter periods can be deemed torture or cruel, inhuman or degrading treatment or punishment, because of the substantial effects on health. ${ }^{4}$

There may be exceptional circumstances when offenders need to be isolated for their own safety or for the safety of others. However, the duration should be as short as possible, for a defined length that is communicated to the offender and with measures in place to reduce health effects. ${ }^{4,7}$ Other options for handling inmates at increased risk of health effects (e.g., youth, those with mental health conditions) should be explored. At its 2014 annual meeting, the Canadian Medical Association passed a resolution, committing to work with Correctional Service Canada to address the medical and psychiatric implications of solitary confinement. ${ }^{9}$ With this initiative and those of the Correctional Investigator and others, we trust that the practice of solitary confinement, first started 200 years ago, will have had its day.

See references, www.cmaj.ca/lookup/suppl/doi:10.1503/cmaj.141419/-/DC1

Competing interests: See www.cmaj.ca/site/misc/cmaj_staff.xhtml

Affiliation: Deputy Editor, CMAJ

Correspondence to: $C M A J$ editor, pubs@cmaj.ca

CMAJ 2014. DOI:10.1503/cmaj.141419 